\title{
The Effect of Self-Esteem on Students' Mathematical Communication Skills
}

\author{
Ibud Mahani ${ }^{1}$, Budiyono ${ }^{2}$, Hasih Pratiwi ${ }^{3}$ \\ 1,2,3 Universitas Sebelas Maret Surakarta; Email: rebut.mahanani@ gmail.com
}

\begin{abstract}
This study aims to find out between students with high, medium, and low self-esteem in term of better mathematical communication. This type of research is quantitative research. The data analysis technique used was one-way variance analysis with inequivalent cells. The collection of students' mathematical communication data was obtained from the score of mathematical communication tests, and the data of self-esteem was collected through questionnaires. The subjects of this study were the eighth-grade junior high school students in Ponorogo with the high, medium and low schools categories. The results of this study indicate that students with high selfesteem possess better mathematical communication skills compared to students with moderate self-esteem and students with low self-esteem. Students with low self-esteem are having the same level of mathematical communication skills as students with moderate self-esteem.
\end{abstract}

Keywords: Mathematical Communication; Self-esteem.

\section{INTRODUCTION}

Mathematics can be used as one of the symbolic languages that allow the realization of communication accurately and precisely. On the other hand, mathematics learning is difficult to be communicated because it is hindered by abstract symbols(Supriadi, 2015). Therefore, the ability to understand a mathematical problem and then changes it into mathematical symbols is an ability needed in mathematics or what is called mathematical communication (Zahara, 2014). Mathematical communication is a tool in the transmission of mathematical knowledge or as a foundation in building mathematical knowledge (Maulani, Suyono, \& Noornia, 2017; Vahlia \& Sudarman, 2015) expressing mathematics in the form of mathematical models and images, and writing answers using their own words. This makes mathematical communication skills is very important to be improved. Although in fact, students' mathematical communication skills in expressing ideas in the form of data presentation into tables and diagrams are still low.(Adesty, Nurhanurawati, \& Widyastuti, 2014).

Regarding the students' low mathematical communication skills, in addition to the cognitive aspects, the effective aspects that can affect the low level of mathematical communication are self-esteem. Self-esteem is an individual's assessment of his own ability, success, usefulness, and kindness (Happy \& Widjajanti, 2014).

Self-esteem has a relationship with a number of life factors including the success of students at school. Students who have high self-esteem can solve their problems independently. The students who have a negative attitude towards mathematics is students who have low selfesteem. This implies that low self-esteem has a detrimental effect on students' achievement, thus, it is necessary to do research on the influence of self-esteem in learning.

There have been several studies discussed the self-esteem (Bruce, 2016; Happy \& Widjajanti, 2014; Kaplanova, 2019; Lumongga, 2012; Rizkianto, Muflikhaki, \& Hernawati, 2013) and several studies in an effort to improve students' mathematical communication skills (Ambarwati, Dwijanto, \& Hendikawati, 2015; Andrianti, Irawati, \& Sudin, 2016; Choridah, 
2013; Hapizah, 2015; Hartati \& Suyitno, 2015; Mahmud \& Hartono, 2014; Maulani et al., 2017; Nurhayati, 2018; Nuriadin, 2015; Permata, Kartono, \& Sunarmi, 2015; Putra, 2016; Supriadi, 2015; Supriadi \& Damayanti, 2016). However, there has been no previous research that examined students' self-esteem towards their mathematical communication skills. Based on the research that has been done before, the renewal in this study lies in seeing the effect of self-esteem on students' mathematical communication skills. So, the purpose of this study is to find out which one provides better mathematical communication skills between students with high, medium, and low self-esteem

\section{THE RESEARCH METHODS}

The type of this research is quantitative. The population in this study were students of the Junior High Schools (SMP) in Ponorogo District, East Java Province, Indonesia. The subjects of this study were Junior High Schools students of the eighth grade from three schools in Ponorogo. The three schools were categorized based on PAMER of 2017 by using stratified cluster random sampling. Each school represents three categories, namely high, medium, and low. Based on the results of the categorization, the school with high category was the SMPN 2 Ponorogo, the school with medium category was SMPN 5 Ponorogo, and the school with low category was SMPN 2 Babadan. The subjects in this study were 249 students which then divided into 3 groups with the following detail: 96 students from the school with a high category, 85 students from the school with medium category, and 68 students from the school with the low category.

Data collection techniques employed in this study were tests and questionnaires. The research instrument consisted of tests of mathematical communication skills and questionnaires of self-esteem. The try-out of the mathematical communication skills test instruments and questionnaires of self-esteem was conducted on 56 students. The mathematical communication test instruments referred to the content validation criteria, item discrimination ( $D \geq 0,3$ ), level of difficulty $(0,3 \leq P \leq 0,7)$, and reliability $\left(r_{11} \geq 0,7\right)$. From 5 tried-out items, there were only 3 items used as tools for collecting data on students' mathematical communication skills. The try-out of the questionnaires of self-esteem referred to the validation criteria of content, internal consistency ( $D \geq 0,3)$, and reliability $\left(r_{11} \geq 0,7\right)$. From 40 tried-out items, only 35 items used as a tool to obtain the data on self-esteem. Furthermore, the data analysis technique in this study was one-way variance analysis with inequivalent cell.

\section{THE RESULTS OF THE RESEARCH AND THE DISCUSSION}

This study was begun by determining the research subjects. The population of this study was all State Junior High School (SMP) students in Ponorogo district which consisted of 54 schools. The subject of this study was the eighth-grade students from three schools in Ponorogo district. Three categories of schools were obtained based on the analysis of the national exam in 2017. The results of the analysis of the categorization of the schools can be seen in Table 1 .

Table 1. Results of Schools Categorization

School Category Name of the School




\begin{tabular}{cc}
\hline High & SMPN 2 Ponorogo \\
Medium & SMP Negeri 5 Ponorogo \\
Low & SMP Negeri 2 Babadan \\
\hline
\end{tabular}

Based on Table 1, the three schools were categorized as high, medium and low categories. The schools with high category were SMP Negeri 2 Ponorogo, the school with medium category was SMP Negeri 5 Ponorogo and the school with low category was SMP Negeri 2 Babadan. The subjects in this study were 249 students where 96 students were taken from the school with high category, 85 students were taken from medium category school, and 68 students were taken from low category school.

In this study, students' mathematical communication data collection techniques used were the test method in the form of description questions that had been validated by experts which then tested to the students in the three schools. Mathematical communication data was used to determine the number of students in three categories, namely high, medium, and low categories. Here are the results of the analysis of students' mathematical communication.

Table 2. Distribution of Students' Mathematical Communication Skills

\begin{tabular}{ccccc}
\hline \multirow{2}{*}{$\begin{array}{c}\text { Self-esteem } \\
\text { Category }\end{array}$} & \multicolumn{3}{c}{ Schools Category } & \multirow{2}{*}{$\begin{array}{c}\text { Number of } \\
\text { Students }\end{array}$} \\
\cline { 2 - 4 } & High & Medium & Low & \\
\cline { 2 - 4 } High & 42 & 28 & 29 & 99 \\
Medium & 34 & 32 & 28 & 94 \\
Low & 20 & 25 & 11 & 56 \\
Number of & 96 & 85 & 68 & 249 \\
Students & & & & \\
\hline
\end{tabular}

Based in Table 2, 99 students possessed high mathematical communication skills, 94 students possessed medium mathematical communication skills, 56 students possessed low mathematical communication skills. From the results of this analysis, it can be seen that the students' mathematical communication in the medium category is higher than the high and low categories, although, in terms of numbers, the difference was not too significant. This can be interpreted that the results of students' mathematical communication skills were not satisfying.

Furthermore, the questionnaire method was used to take the self-esteem date. The questionnaire instrument was been validated by experts and then answered by the research subjects. The questionnaire of self-esteem was used to determine the number of students with high, medium, and low self-esteem categories in each school. Here are the results of the questionnaire analysis students' self-esteem.

Table 3. The Distribution of Self-esteem

\begin{tabular}{|c|c|c|c|c|}
\hline \multirow{2}{*}{$\begin{array}{l}\text { Self-Esteem } \\
\text { Category }\end{array}$} & \multicolumn{3}{|c|}{ Schools Category } & \multirow[t]{2}{*}{ Number of Students } \\
\hline & High & Medium & Low & \\
\hline
\end{tabular}




\begin{tabular}{llllc} 
High & 28 & 32 & 21 & 81 \\
Medium & 44 & 33 & 31 & 108 \\
Low & 24 & 20 & 16 & 60 \\
$\begin{array}{l}\text { Number of } \\
\text { Students }\end{array}$ & 96 & 85 & 68 & 249 \\
\hline
\end{tabular}

Based on Table 3, there were 81 students with high self-esteem, 108 students with medium self-esteem, and 60 students low self-esteem. From the analysis, the students with medium self-esteem were higher in number than the students with high and low self-esteem. The number of students in each category was not too significantly different. In addition, based on table 3, it can also be interpreted that students with high self-esteem were lesser in number than the overall student's self-esteem. This means that there were still many students who negatively assessed themselves which then contributed to their low mathematical communication skills. Furthermore, the results of the categorization analysis of the students' mathematical communication skills and students' self-esteem can be seen in Table 4 .

Table 4. The Categorization of the Students' Mathematical Communication Skills and Self-Esteem

\begin{tabular}{ccccc}
\hline $\begin{array}{c}\text { Mathematical } \\
\text { Communication Category }\end{array}$ & \multicolumn{3}{c}{ Self-Esteem Category } & \multirow{2}{*}{$\begin{array}{c}\text { Number of } \\
\text { Students }\end{array}$} \\
\cline { 2 - 4 } & High & Medium & Low & \\
\cline { 2 - 4 } High & 38 & 31 & 18 & 87 \\
Medium & 23 & 40 & 19 & 82 \\
Low & 24 & 35 & 21 & 80 \\
Number of Students & 85 & 106 & 58 & 249 \\
\hline
\end{tabular}

Based on Table 4, the high mathematical communication skills were more dominantly owned by students with high self-esteem category. Students with high self-esteem category possessed a positive personality, willing to strive, always eager to do the work and not easy to succumb to failure, capable of resolving the problems in the mathematics learning, thus affecting the results of mathematical communication skills. The medium mathematical communication skills were more dominantly owned by students with medium self-esteem category characterized by their low fondness toward challenges so that in learning, they lack confidence in their own abilities. The low mathematical communication skills were more dominantly owned by students with low self-esteem category. Students with low self-esteem category tended to have negative personality traits, lack of confidence, lack of motivation to do tasks well, unable to stimulate themselves, thus, affecting their mathematical communication skill.

To find out which one provides better mathematical communication skills between students with high, medium, and low self-esteem, this study employed one-way variance analysis with inequivalent cells because the size of the samples at each school was not the same. The data from the analysis to be used in the one-way ANAVA with inequivalence cells statistical test can be seen in Table 5 . 
Table 5. The Description of Students' Self-Esteem

\begin{tabular}{ccccccc}
\hline $\begin{array}{c}\text { Self- } \\
\text { esteem } \\
\text { Category }\end{array}$ & N & Mean & $\begin{array}{c}\text { Std. } \\
\text { Deviation }\end{array}$ & Std. Error & Minimum & Maximum \\
\hline High & 86 & 50.19 & 14.126 & 1.523 & 22 & 73 \\
Medium & 105 & 44.13 & 15.204 & 1.484 & 9 & 76 \\
Low & 58 & 40.34 & 15.604 & 2.049 & 9 & 65 \\
Total & 249 & 45.34 & 15.359 & 973 & 9 & 76 \\
\hline
\end{tabular}

Based on Table 5, the data to be used for statistical tests was obtained. After the students' mathematical communication skills and self-esteem had been categorized into high, medium, and low, one-way ANOVA with inequivalent cells was carried out. The question is whether the three categories of self-esteem gave the same effect on students' mathematical communication skills (as $\mathrm{H}_{0}$ ), or at least there are two categories that do not have the same effect on students' mathematical communication (as $\mathrm{H}_{1}$ ). The results of the statistical tests can be seen in Table 6 .

Table 6. The Summary of the Variance Analysis

\begin{tabular}{cccccc}
\hline & Sum of Squares & Df & Mean Square & F $_{\text {obs }}$ & P \\
\hline $\begin{array}{c}\text { Between } \\
\text { Groups }\end{array}$ & 3619,724 & 2 & 1809,862 & 8.113 & .000 \\
$\begin{array}{c}\text { Within } \\
\text { Groups }\end{array}$ & 54880.260 & 246 & 223.090 & - & - \\
Total & 58499.984 & 248 & & - & - \\
\hline
\end{tabular}

Based on Tables 6 , it appears that the $\mathrm{F}_{\mathrm{obs}}=8.113$ and $\mathrm{p}<0.05, \mathrm{H}_{0}$ is rejected. In conclusion, it is not true that the three categories of self-esteem equally affect the students' mathematical communication skills. Furthermore, a test with the Scheffe method was carried out to find out which ones provide better mathematical communication between students with high, medium, or low self-esteem. The result of the test is presented in Table 7.

Table 7. Multiple Comparisons with Scheffe Method

\begin{tabular}{ccccc}
\hline & (I) Self-esteem & (J) Self-esteem & Mean Difference (I-J) & P \\
\hline \multirow{2}{*}{ Scheffe } & High & Medium & $6053^{*}$ & .022 \\
& \multirow{3}{*}{ Medium } & Low & $9841^{*}$ & .001 \\
& High & $-6053^{*}$ & .022 \\
& Low & 3789 & .302 \\
& Low & High & $-9841^{*}$ & .001 \\
& & Medium & -3789 & .302 \\
\cline { 3 - 4 }
\end{tabular}

Based on Table 7, it is known that the comparison of mathematical communication skills between students with high and medium self-esteems is $\mathrm{p}(\mathrm{sig})=, 022<0.05$, then $\mathrm{H}_{\mathrm{o}}$ is rejected. This means that students with high self-esteem do not have the same mathematical communication as students with medium self-esteem. By looking at the mean, it can be 
concluded that students with high self-esteem have better mathematical communication skills than students with medium self-esteem. Comparison of mathematical communication between students with low and high self-high is $\mathrm{p}(\mathrm{sig})=.001<0.05$. By looking at the mean, it can be concluded that students with high self-esteem have better mathematical communication skills than students with low self-esteem. Comparison of mathematical communication between students with medium and low self-esteem is $\mathrm{p}(\mathrm{sig})=, 302>0.05$. This means that students with medium self-esteem are having the same mathematical communication as students with low self-esteem.

Based on the test statistical analysis above, it can be concluded that students with high self-esteem have better mathematical communication skills compared to the students with low and medium self-esteem. Students with medium self-esteem category are having the same mathematical communication skills with students with low self-esteem.

\section{CONCLUSION AND SUGGESTION}

Based on the results of the research and discussion, it can be concluded that students with high self-esteem have better mathematical communication skills compared to students with low and medium self-esteem. Students with medium self-esteem category are having the same mathematical communication skills with students with low self-esteem.

The suggestion that can be given to the teachers and prospective teachers is to pay attention to the self-esteem that students posses because it can affect students' mathematical communication. It is also suggested for the further researcher to try to examine the self-esteem of other students' abilities.

\section{REFERENCES}

Adesty, M., Nurhanurawati, \& Widyastuti. (2014). Pengaruh Model Pembelajaran Kooperatif Tipe NHT Terhadap Kemampuan Komunikasi Matematis dan Belief. Jurnal Pendidikan Matematika Unila, 2(2).

Ambarwati, R., Dwijanto, \& Hendikawati, P. (2015). Keefektifanmodel Project-Based Learning Berbasis GQM Terhadap Kemampuan Komunikasimatematis Dan Percaya Diri Siswa Kelas VII. Unnes Journal of Mathematics Education, 1(1), 180-186.

Andrianti, R. Y., Irawati, R., \& Sudin, A. (2016). Pengaruh Pendekatan SAVI (Somatic, Auditory, Visual, Intellectual) dalam Meningkatkan Kemampuan Komunikasi Matematis dan Motivasi Belajar Siswa Sekolah Dasar pada Materi Pengolahan Data. Jurnal Pena Ilmiah, 1(1), 471-480.

Bruce, D. (2016). Body Type, Self-esteem and Assertiveness among High School Student in Ghana. Journal Adcocacy, Research and Education, 6(2), 105-112.

Choridah, D. T. (2013). Peran pembelajaran berbasis masalah untuk meningkatkan kemampuan komunikasi dan berpikir kreatif serta disposisi matematis siswa SMA. Jurnal Ilmiah Program Studi Matrmatika STKIP Siliwangi Bandung, 2(2), 194-202.

Hapizah. (2015). Peningkatan Kemampuan Penalaran Matematis, Komunikasi Matematis, dan 
Kemandirian Belajar Mahasiswa Calon Guru Matematika Melalui Blended Learning dengan Strategi Probing-Prompting. Bandung: SPs UPI.

Happy, N., \& Widjajanti, D. B. (2014). Keefektifan PBL Ditinjau Dari Berfikir Kritis Dan Kreatif Matematis, Serta Self-esteem Siswa SMP. Jurnal Riset Pendidikan Matematika, $1(1), 48-57$.

Hartati, T., \& Suyitno. (2015). Studi Komparatif Model Pembelajaran TAI Dan CIRC Terhadap Kemampuan Komunikasi Matematis Siswa. Unnes Journal of Mathematics Education, $4(1), 60-68$.

Kaplanova, A. (2019). Self-esteem, anxiety and coping strategies to manage stress in ace hockey. Acta Gymnica, 49(1), 10-15.

Lumongga, N. (2012). The Effect Of Cognitive Behavorial Therapy Group and Social Support Group on the Self Esteem among Breast Cancer Patients. Makara Journal of Health Research, 15(2), 65-72.

Mahmud, D. A., \& Hartono. (2014). Keefektifan Model Pembelajaran ISK dan Ditinjau dari Motivasi, Sikap dan Kemampuan Komunikasi Matematis. Jurnal Riset Pendidikan Matematika, 1(2), 188-201.

Maulani, D., Suyono, \& Noornia, A. (2017). Pengaruh Penerapan Model Reciprocal Teaching Terhadap Kemampuan Komunikasi Matematis Ditinjau Dari Self-Concept Siswa di SMAN Kecamatan Tambun Selatan Bekasi. JPPM, 10(2), 14-24.

Nurhayati, N. (2018). Pengembangan Perangkat Bahan Ajar Pada Pembelajaran Matematika Realistik Indonesia Untuk Meningkatkan Kemampuan Komunikasi Matematis Siswa. Fibonacci : Jurnal Pendidikan Matematika Dan Matematika, 3(2), 121-136.

Nuriadin, I. (2015). Pembelajaran Kontekstual Berbantuan Program Geometer's Sketchpad Dalam Meningkatkan Kemampuan Koneksi Dan Komunikasi Matematis Siswa SMP. Jurnal Ilmiah Program Studi Matrmatika STKIP Siliwangi Bandung, 4(2), 168-181.

Permata, C., Kartono, \& Sunarmi. (2015). Analisis Kemampuan Komunikasi Matematis Siswa Kelas VIII SMP Pada Model Pembelajaran TSTS Dengan Pendekatan Scientific. Unnes Journal of Mathematics Education, 4(2), 127-133.

Putra, F. G. (2016). Pengaruh Model Pembelajaran Reflektif dengan Pendekatan Matematika Realistik Bernuansa Keislaman terhadap Kemampuan Komunikasi Matematis. Al-Jabar: Jurnal Pendidikan Matematika, 7(2), 203-210.

Rizkianto, R., Muflikhaki, I., \& Hernawati, N. (2013). Nilai Ekonomi Anak, Motivasi dan Self Esteem Pekerja Anak. Jurnal Ilmu Keluarga Dan Konsumen, 6(3), 172-179.

Supriadi, N. (2015). Pembelajaran Geometri Berbasis Geogebra Sebagai Upaya Meningkatkan Kemampuan Komunikasi Matematis Siswa Madrasah Tsanawiyah (MTs). Al-Jabar: Jurnal Pendidikan Matematika, 6(2), 99-109.

Supriadi, N., \& Damayanti, R. (2016). Analisis Kemampuan Komunikasi Matematis Siswa Lamban Belajar Dalam Menyelesaikan Soal Bangun Datar. Al-Jabar: Jurnal Pendidikan 
Matematika, 7(1).

Vahlia, I., \& Sudarman, S. W. (2015). Penerapan model pembelajaran berbalik ( reciprocal teaching ) ditinjau dari aktivitas dan hasil belajar siswa. Jurnal Pendidikan Matematika FKIP Univ. Muhammadiyah Metro, 4(1), 59-66.

Zahara, S. (2014). Peningkatan Kemampuan Penalaran Logis dan Komunikasi Matematis Melalui Model Pembelajaran Kooperatif Tipe Think Pair Share (TPS) di SMP Negeri 24 Medan. Jurnal Pendidikan Matematika Paradikma, 7(3). 